\title{
Principles of the formation of tourism and recreation complexes (example of Rozhdestveno, Leningrad Oblast, Russia)
}

\author{
Olga Kokorina ${ }^{1, *}$, Fedor Perov ${ }^{1}$, and Rashid Mangushev ${ }^{1}$ \\ ${ }^{1}$ St. Petersburg State University of Architecture and Civil Engineering, 190005, 2nd \\ Krasnoarmeyskaya St., 4, St. Petersburg, Russia
}

\begin{abstract}
The paper presents research materials and analysis of urban planning factors that influenced decision-making in the formation of projects of tourism and recreation complexes in the Leningrad Oblast. The objective of the study was to identify, analyze and generalize the historical and cultural potential of the territory, the totality of factors affecting the development and attraction of people to this territory, and the formation of a rich, comfortable residential and tourist environment.
\end{abstract}

\section{Introduction}

The problem of development of the urban planning structure of tourism plays a huge role in the formation of large agglomerations, but small towns of Russia are an even more priority area for study. According to the census of the Federal State Statistics Service on January 1, 2016 , more than $16 \%$ of the country's population lives in more than 788 small towns (which makes $71 \%$ of all towns in Russia). Most of the small towns and settlements of Russia are in critical condition, representing a loose urban planning structure with monofunction. Compared with regional centers and megacities, they are especially acutely affected by the global economic crisis and political upheavals of the 90s. [1] [1] At the same time, there is an excessive concentration of functions in all the main cities of Russia and Europe, which are a monocentric system. Unloading monocenters and partly transferring social activity to other settlements creates the opportunity to solve many problems associated with overpopulation, traffic congestion, circular migration and the city's green environment. [2]

Ways to solve these problems through the creation of centers for the development of a rural settlement based on recreation and tourism complexes are characteristic of the settlements of the Leningrad Oblast. Tourism is one of the most dynamically developing industries that can give impetus to the development of such settlements. Tourism will not only receive funding, attract more people to Russian culture, provide a sufficient number of jobs, but also subsequently create conditions for the further development of the whole settlement as an independent urban development unit - a polycentre. [2]

The polycentric structure is a branched composition of subcenters, diverging from the main, starting point for the development of agglomeration. The considered level is the

${ }^{*}$ Corresponding author: olga.kokorina@gmail.com 
municipal district system, where St. Petersburg is represented as the main center (metropolitan area), and settlements in the areas associated with the priority areas of development of the Leningrad Oblast are represented as polycentres.

Important factors affecting the development of tourism are: natural, historical and cultural resources of the territory; location of tourism facilities in relation to transport communications; state of the functional and planning structure of the settlement; potential for tourist use. The combination of the rich cultural and historical heritage of the Leningrad Oblast, as well as its richness in natural resources, contributes to the development of various types of tourism in the territory: cultural, educational, business, event, pilgrimage, water, rural, ecological, etc. [3]

The revealed concentration of tourism development resources of the Leningrad Oblast helped formulating the main areas that have potential for development in the form of subcentres of a polycentric structure, such as: Staraya and Novaya Ladoga, Tikhvin, Gatchina-Rozhdestveno-Luga, Vyborg, as well as a direction towards Priozersk and Kingisepp. Each sub-center has its own characteristics of the territory regeneration based on the natural conditions, geographical position, historically developed life.

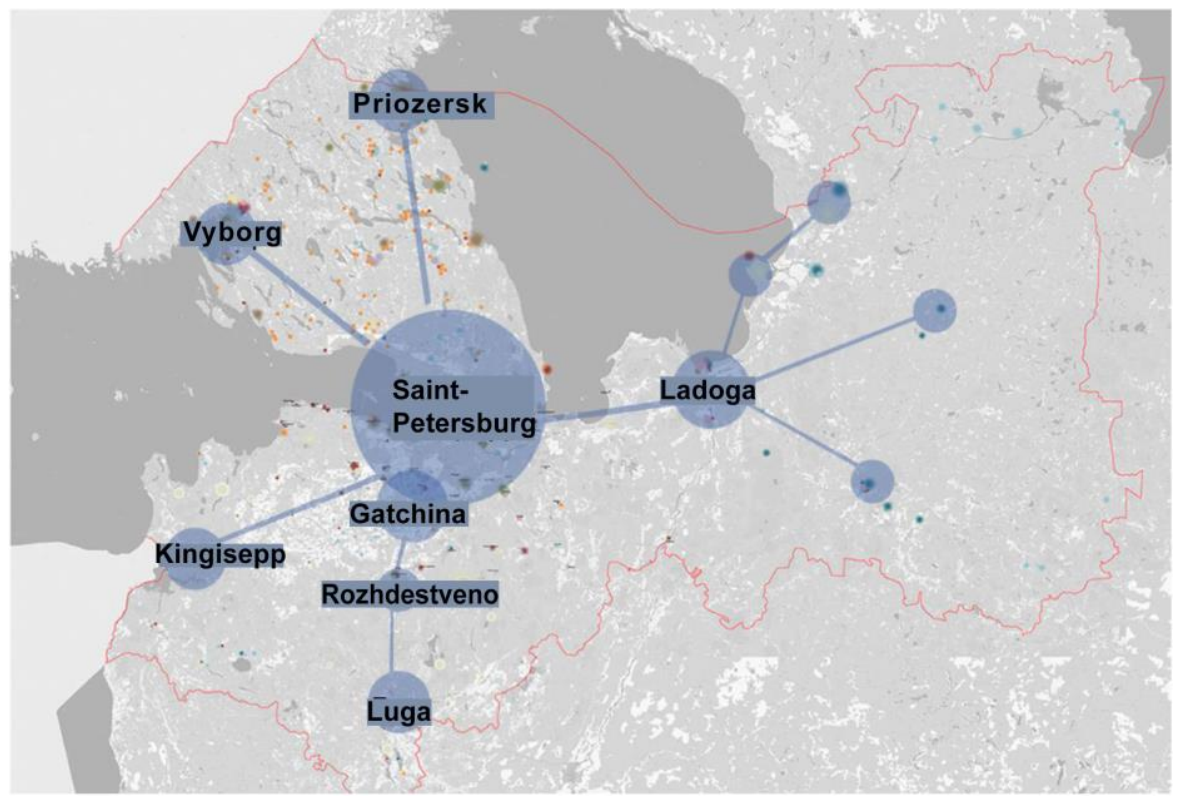

Fig. 1. General map of the development of the Leningrad Oblast.

\section{Materials and methods}

The rural settlement of Rozhdestveno is located in the Gatchina district of the Leningrad Oblast and is the administrative center. The territory has a rich historical and cultural potential - temples and manors, Rozhdestveno park ensembles. From 1780 to 1796, Rozhdestveno was a town, but the historical and town-planning structure of the settlement was almost lost. [4] The main facilities are semi-abandoned and dilapidated.

The main natural resources of the territory: karst caves, springs with drinking water, red sandstones along the banks of the Oredezh River, one of the largest rivers of the Leningrad Oblast. 

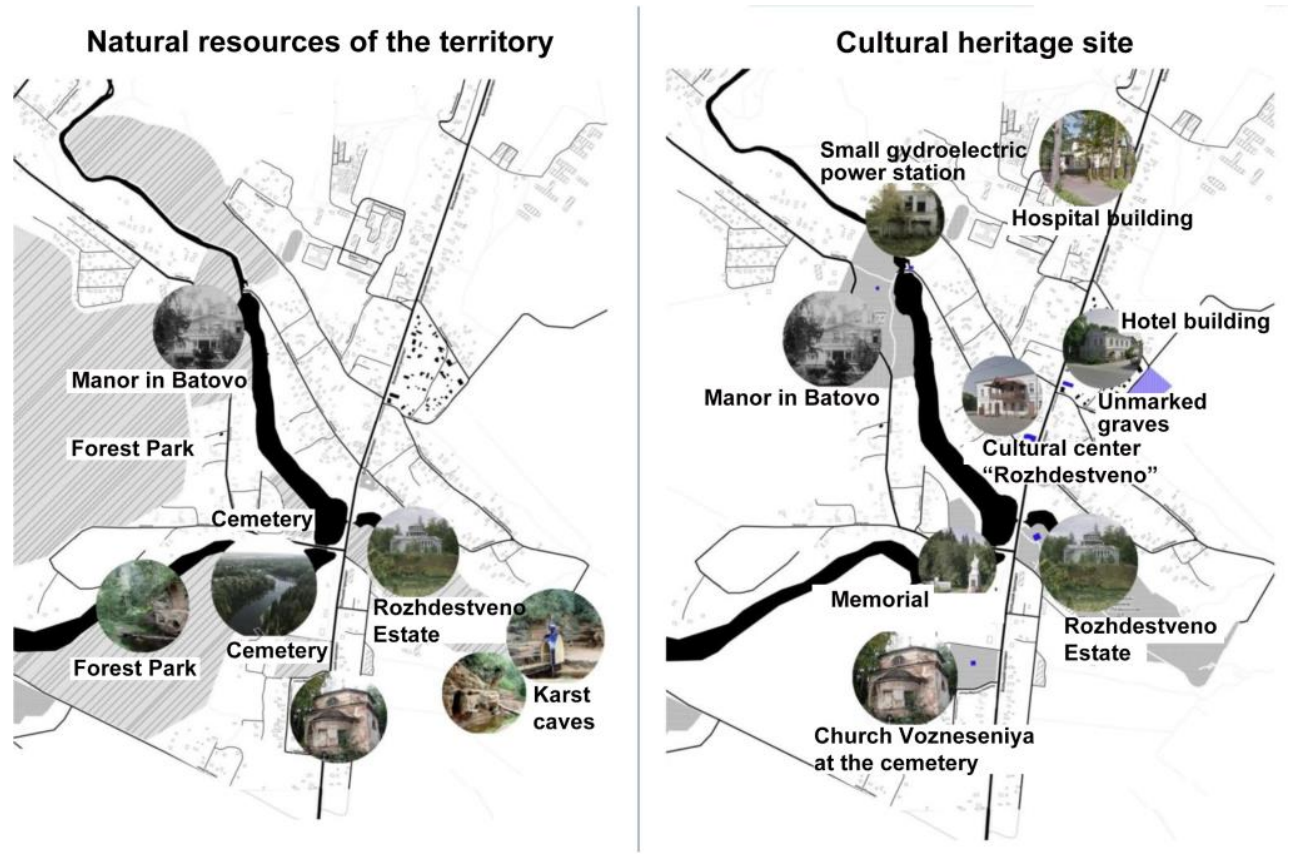

Fig. 2. Map of natural resources and cultural heritage in Rozhdestveno.

In the planning system of the "tourist region", it seems important to place objects of tourist attraction relative to the existing and reconstructed street-road network. (Fig. 3) 

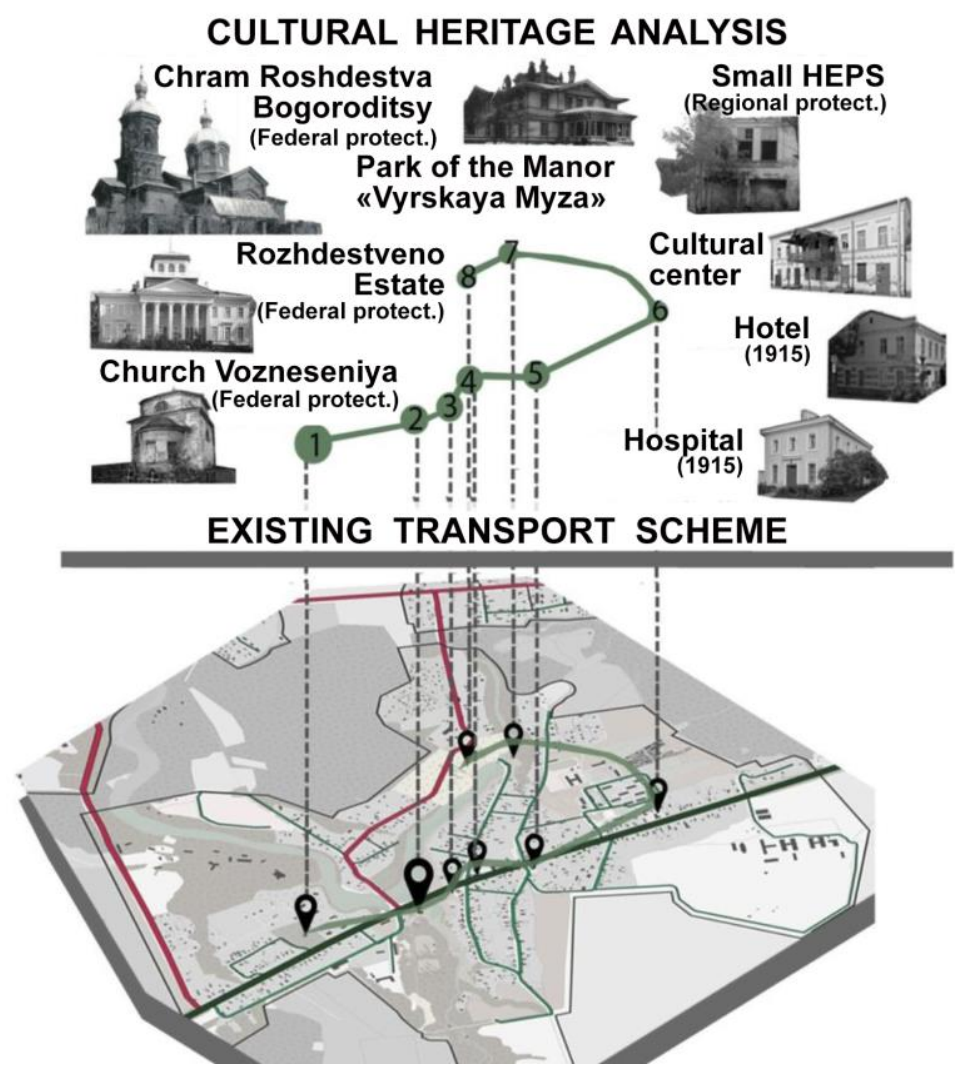

Fig. 3. Placement of objects of historical and cultural heritage relative to the transport scheme of Rozhdestveno.

At the moment, in the territory under consideration, there is only a public transport connection with the sub-center (Gatchina) and center of the agglomeration - St. Petersburg. Siverskaya railway station is in $9 \mathrm{~km}$ from Rozhdestveno.

From the point of view of the functional and planning structure of the settlement, most of the territory is currently occupied by individual residential buildings and multi-apartment buildings, which are subject to major repairs. These are mainly 2-3-storey houses built between 1971 and 1990. [3] Along the main highway, Kievskoe shosse, there are retail premises, a hospital, a hotel, and cafes. There are one preschool and two schools. Sports facilities include 3 sports halls and 2 sports grounds. Religious activities are carried out by 2 operating temples and 1 chapel. (Fig. 4) 


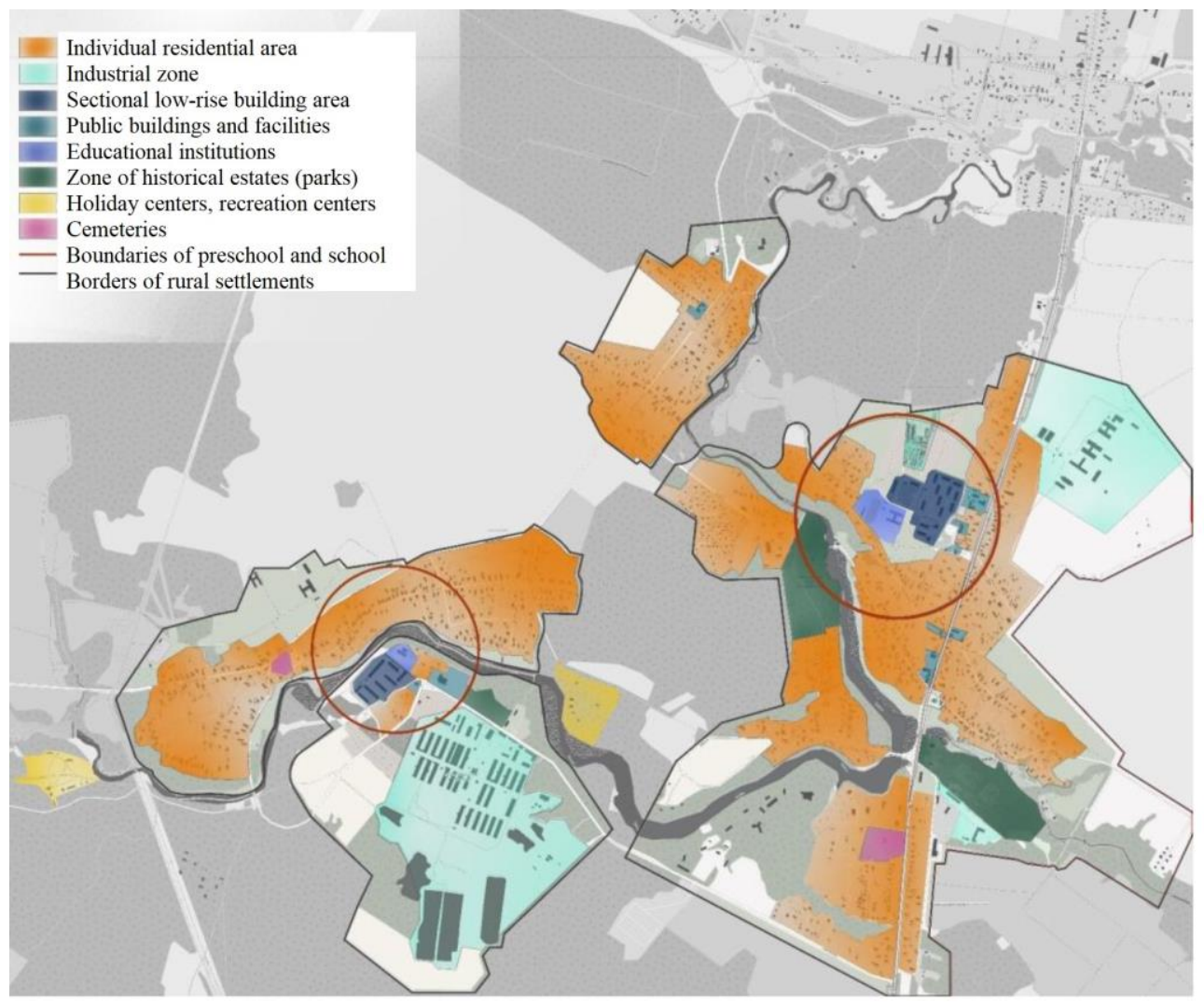

Fig. 4. Scheme of functional zoning of Rozhdestveno.

\section{Results and discussion}

According to the results of the study, the territory of the settlement of Rozhdestveno can be described as destructed and incomplete, and the environment in general as partially ruined. The main tasks of solving urban development problems of the settlement are:

- formation of a comfortable road network inside the settlement, creation of a pedestrian and bicycle infrastructure;

- creation and improvement of busy public spaces: city squares, yards, parks, markets;

- creating opportunities for pastime of the population of all age categories. It is important to create modern spaces that have the prerequisites for the development of art or creativity, capable of taking the town to a new stage of socio-economic development;

- updating and restoring town sights: For each person, the history of the town is a reason for pride in their native land, which brings together different generations;

- landscaping and solving problems such as street lighting, repair of pedestrian bridges, landscaping of children's and recreational areas, equipping sports grounds;

- updating or creating social infrastructure facilities: increasing the number of places in preschools and schools, and creating the social infrastructure of the settlement;

- activation of abandoned or inefficiently used buildings and premises (within the framework of the project - restoration of a small hydroelectric power station and Cultural Center "Rozhdestveno").

In the framework of the master's thesis, the basis for the concept of development of the master plan of the rural settlement of Rozhdestveno was the following: 
Based on the analysis made, analysis of the urban development situation and the considered positive aspects and problems of the territory under development, three areas of tourism that can balance the development of the territory are identified.

1. The main area of development is recreational tourism. This decision is caused by the high potential for the development of the territory in a short period of time with a sufficiently developed infrastructure.

2. The second most important and the main one for tourist attraction is cultural and educational tourism. This area is characterized by the presence of historical and architectural monuments. However, it involves significant risks due to the competitive nearby regions, high costs for the reconstruction of cultural objects.

3. The area of business tourism has significant potential. This area is characterized by a high potential for the development of the territory due to multifunctionality and availability of developed infrastructure.

As part of the proposed settlement renovation program for the development of tourism potential, it is planned to form a settlement structure with a pronounced center and subcenters of the rural settlement, interconnected by alleys and green corridors, gardens and green public spaces. (Fig. 5) This scheme allows maximum use of the town-planning potential of the site, which was identified by preliminary study. 


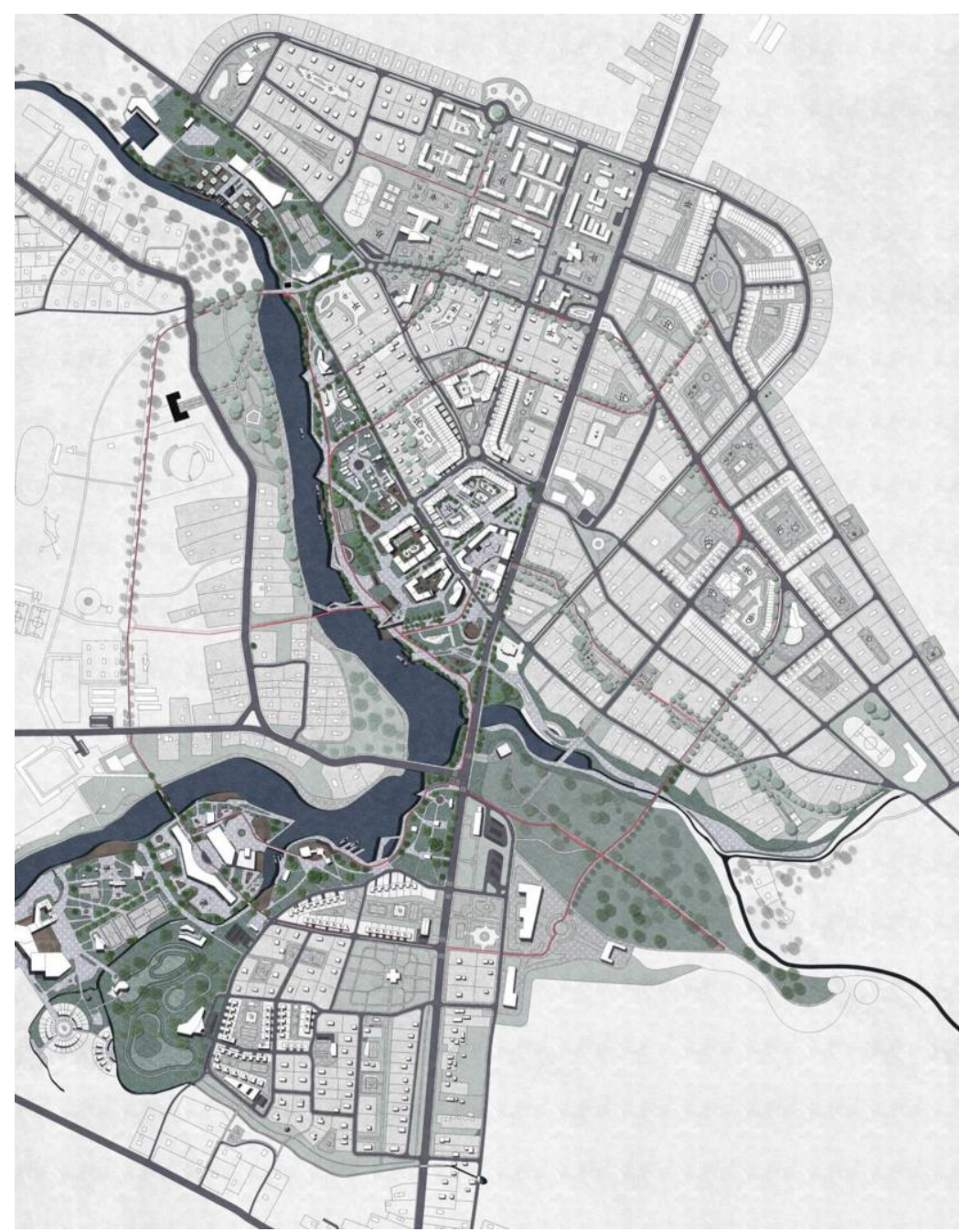

Fig. 5. Concept of the development of the settlement of Rozhdestveno.

\section{Conclusion}

In accordance with the development of the concept of "tourism-recreation land", the use of the natural landscape and the relationship with the cultural and historical objects of the settlement, the maximum preservation of the existing planning, transport and road network are proposed. Creation and addition of new functions and organization of public spaces is carried out through the use of unused areas of the settlement, as well as the restoration of historic buildings. In the center of Rozhdestveno, residential wooden buildings are being formed near the newly created embankment along Zavodskaya Street. Implementation of a green recreational belt along the Oredezh River implies a change in the functional structure of this site - creation of the "Russian village". The transformation of this territory will allow preserving the existing wooden private houses, creating a new public space oriented both to the inhabitants of the settlement and to tourists of this region, preserving the "spirit of the place". The main idea of reconstruction at the town-planning level is to organize new green corridors, which in turn can be tourist routes along which the main objects of infrastructure 
and tourism will be located, as well as serve as links between residential and public areas of the settlement.

Thus, on the basis of the revealed features of the studied settlement, a multifunctional tourist center is created, attracting the interests of tourists, which can form the development potential of the settlement and the entire Gatchina district.

\section{References}

1. O. G. Kokorina, N.R. Gerasimchuk, A.M. Musin, D.I. Yakovlev, Collection of proceedings of the IX Creative Forum "Architectural Seasons at SPbGASU, 96 (2019)

2. N.R. Gerasimchuk, O.G. Kokorina, Collection of proceedings of the 71st All-Russian Scientific and Practical Conference of students, graduate students and young scientists, SPbGASU, SPb (2019)

3. Program of socio-economic development of the Leningrad Oblast for 2012 - 2016. Electronic resource: http://textarchive.ru/c-1963608-pall.html

4. A.S. Kuskov, Basics of tourism (p. 400, Knorus, Moscow, 2008)

5. L. Lavrov, F. Perov, Architecture and Engineering, 3(3), 4-10, 2018

6. O. Fedorov, V. Lazina, Architecture and Engineering, 4(4), 1 (2019)

7. L. Lavrov, F. Perov, Architecture and Engineering, 4(1), 4-10 (2019)

8. M.J. Kane, R. Zink, Leisure Studies, 23(4), 329-345 (2004) doi:10.1080/0261436042000231655

9. J. Larsen, Leisure Studies, 27(1), 21-34 (2008) doi:10.1080/02614360701198030

10. L. Mundet, G. Coenders, Journal of Sustainable Tourism, 18(5), 657-674 (2010) doi:10.1080/09669581003668524 